\title{
DIGITAL MODEL FOR SIMULATED EFFECTS \\ OF GROUND-WATER PUMPING IN THE \\ HUECO BOLSON, EL PASO AREA, TEXAS, NEW MEXICO, AND MEXICO
}

\section{U.S. GEOLOGICAL SURVEY}

Water-Resources Investigations 58-75
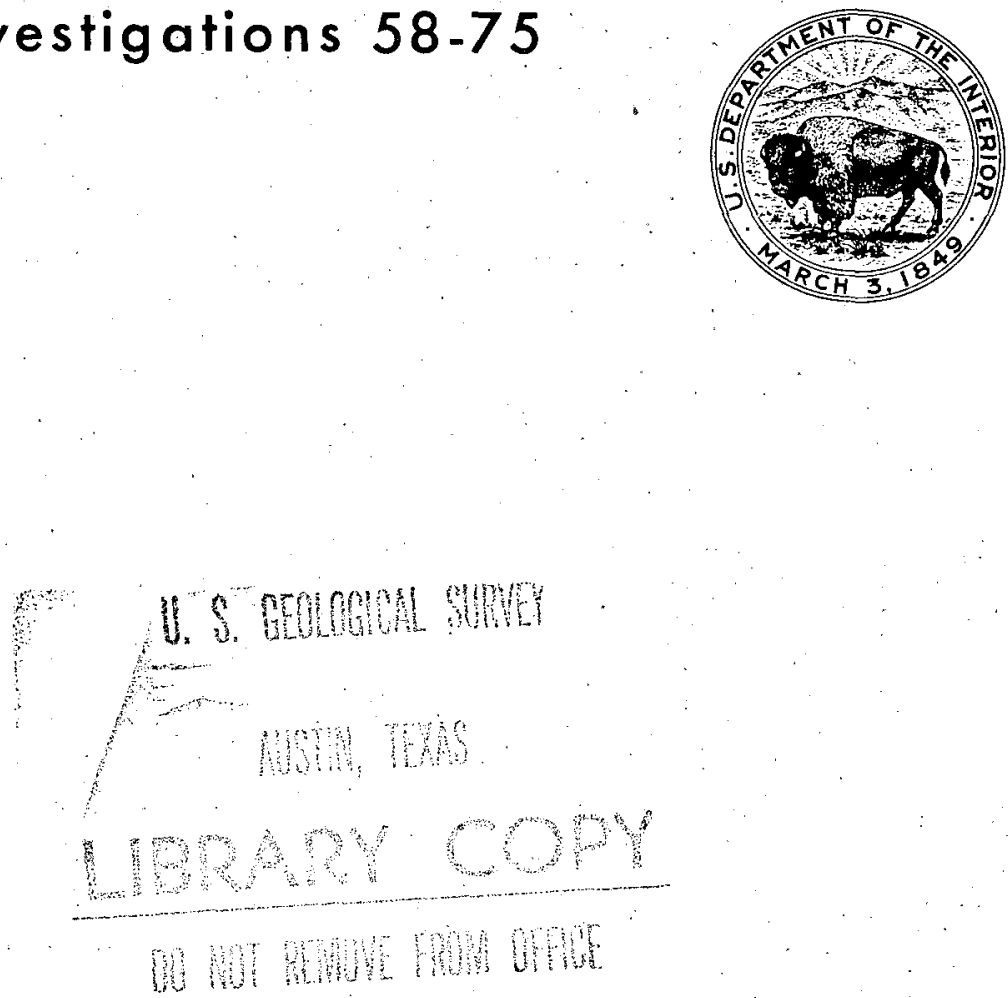

Prepared by the U.S. Geological Survey in cooperation with the city of El Paso and the Texas.Water Development Board 


\section{DIGITAL MODEL FOR SIMULATED EFFECTS OF GROUND.W ATER PUMPING IN THE HUECO BOLSON, EL PASO AREA, TEXAS, NEW MEXICO, AND MEXICO}

By W.R. Meyer

U.S. GEOLOGICAL SURVEY

Water-Resources Investigations 58-75

Prepared by the U.S. Geological Survey in cooperation with the city of El Paso and the Texas Water Development Board

APRIL 1976 


\title{
UNITED STATES DEPARTMENT OF THE INTERIOR
}

Thomas S. Kleppe, Secretary

\author{
GEOLOGICAL SURVEY \\ V.E. McKelvey, Director
}

FOR ADDITIONAL INFORMATION WRITE TO:

U.S. GEOLOGICAL SURVEY

FEDERAL BUILDING

300 EAST 8TH STREET

AUSTIN, TX 78701 


\section{CONTENTS}

Page

Abstract-1-

Introduction-........ 2

Purpose and scope of this report-_... 4

Previous investigations-_. 4

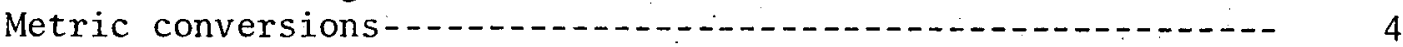

Geohydrology of the Hueco Bolson-_. 5

Ground-water recharge, movement, 'and dischàrge-_........- 6

Changes in water levels 6

Fresh water in storage-...... 8

Construction and use of the digital mode1- 14

Construction and calibration-.... 14

Simulations of water-level changes-_... 24

Summary and conclusions-_... 27

References cited.... 31 
Figure 1. Map showing locations of wells and variable grid pattern used for modeling the northwestern half of the Hueco Bolson-..................................

2. Graph showing estimated average daily pumpage from deep wells, 1906-73

3. Map showing approximate water-level contours in 1903-.- 9 9

4. Map showing approximate water-level contours in

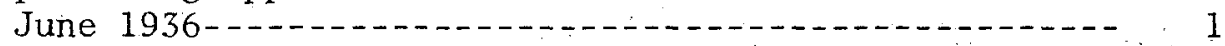

5. Map showing approximate decline in water levels,

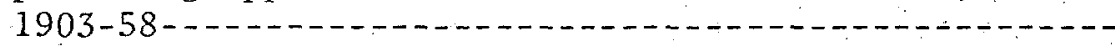

6. Map showing approximate decline in water levels,

7. Map showing approximate thickness of deposits

8. Map showing approximate transmissivities of the

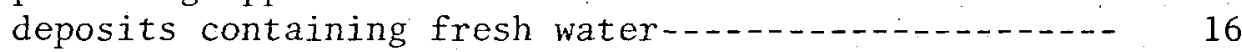

9. Map showing approximate water-level contours in 1903 as computed by the digital model-.............

10. Map showing approximate water-1evel contours in January 1936 as computed by the digital model.......-

11. Map showing decline in water levels for 1903-58 as computed by the digital model-.....................

12. Map showing decline in water levels for 1903-73 as . computed by the digital mode1.........................

13. Map showing predicted decline in water levels for 1903-91 as computed by the digital mode1-.......-.--

\section{TABLES}

Table 1. Average annual seepage to or from the Rio Grande and average leakage between aquifers-.............-.

2. Amount of fresh water in storage in the Texas part of the bolson and amount removed from storage in

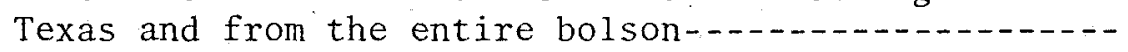


DIGITAL MODEL FOR SIMULATED EFFECTS OF GROUND-WATER PUMPING

IN THE HUECO BOLSON, EL PASO AREA,

TEXAS, NEW MEXICO, AND MEXICO

By

W. R. Meyer

U.S. Geological Survey

\begin{abstract}
The Hueco Bolson provides a substantial part of the municipal and industrial water supply of the El Paso area of Texas, New Mexico, and Mexico. Although the supply of fresh ground water in the bolson is large, about $10.6 \mathrm{million}$ acre-feet $\left(13,070 \mathrm{hm}^{3}\right)$ in 1973 in the Texas part of the bolson alone, the supply is being depleted.

A two-layer digital model of the Hueco Bolson was developed to duplicate the historic changes in water levels and the predevelopment (1903) water surface, and to predict the response of the hydrologic system to any plan of water development.

The model. study showed that a proposed plan of development for. 1973-91, in which pumping would be increased by 29 percent in the Texas part of the bolson and by 34 percent in Ciudad Juarez, would cause additional waterlevel declines of as much as 45 feet $(13.7 \mathrm{~m})$ in the vicinity of El Paso and 70 feet $(21.3 \mathrm{~m})$ in Ciudad Juarez. The study also showed that nearly 60 percent of the water would come from storage in the water-table part of the bolson aquifer (model layer 2) and 28 percent from leakage from the alluvium. (model layer 1). By the end of the period, 9.84 million acrefeet $\left(12,133 \mathrm{hm}^{3}\right)$ of fresh water would be in storage in the Texas part of the bolson, as compared to $10.6 \mathrm{mil1ion}$ acre-feet $\left(13,070 \mathrm{hm}^{3}\right)$ in storage in 1973 .
\end{abstract}


The availability of water in the El Paso area to meet the rapidly growing demands for industrial use and municipal supply concerns not only the residents, but also the state and Federal governments. The economic development of the community, as we11 as the existence of military installations such.as Fort Bliss, is dependent chiefly upon the use of ground water pumped from the northwestern part of the Hueco Bolson (fig. 1 ).

The area of the Hueco Bolson includes all of E1 Paso County between the Franklin and Hueco Mountains in the extreme western part of Texas and extends northward into New Mexico and southward into Mexico. The area modeled extends about 19 miles $(30.6 \mathrm{~km})$ into New Mexico and includes part of the Tularosa Basin. The El Paso Chamber of Commerce estimated that in 1970, the population of this area was about 752,000, of which 341,000 were in E1 Paso and 411,000 were in Ciudad Juarez, Mexico.

The supply of fresh ground, water in the bolson, although large, is being depleted; the annual withdrawals far exceed the annual recharge. Ground-water development is further complicated by the occurrence of saline water that everywhere underlies, in the artesian part of the bolson overlies, and along the eastern and southeastern parts of the bolson adjoins the fresh water. Haphazard development of the fresh-water supply in the bolson could result in movement of the saline water into parts of the aquifer that previously contained fresh water.

Prior to 1965, techniques for analyzing the hydrologic data collected since 1935 relied upon mathematical methods that were not only time consuming but also assumed an idealized ground-water flow system. As development of the aquifer increased, the idealized methods of analysis were no longer satisfactory for management decisions, and more effective tools were required.

In 1965, an electrical-analog model (Leggat and Davis, 1966) was deve1oped to better define the aquifer system and to simulate responses of the reservoir to the many ways in which it might be developed in the future. The model was considered to be analogous to the physical system when its response to pumping resulted in water-level declines that duplicated reasonably well the historical declines. However, the effectiveness of the analog model to predict the response of the aquifer to a particular plan of development was severely reduced in 1969, when a part of the Rio Grande channel was straightened and lined with concrete. The Geological Survey and its cooperators in this study concluded that it.would be more effective to develop a digital model than to rebuild the analog model, inasmuch as a digital model would be required in the near future to model the temporal and spatial variations in the chemical quality of the ground water. 


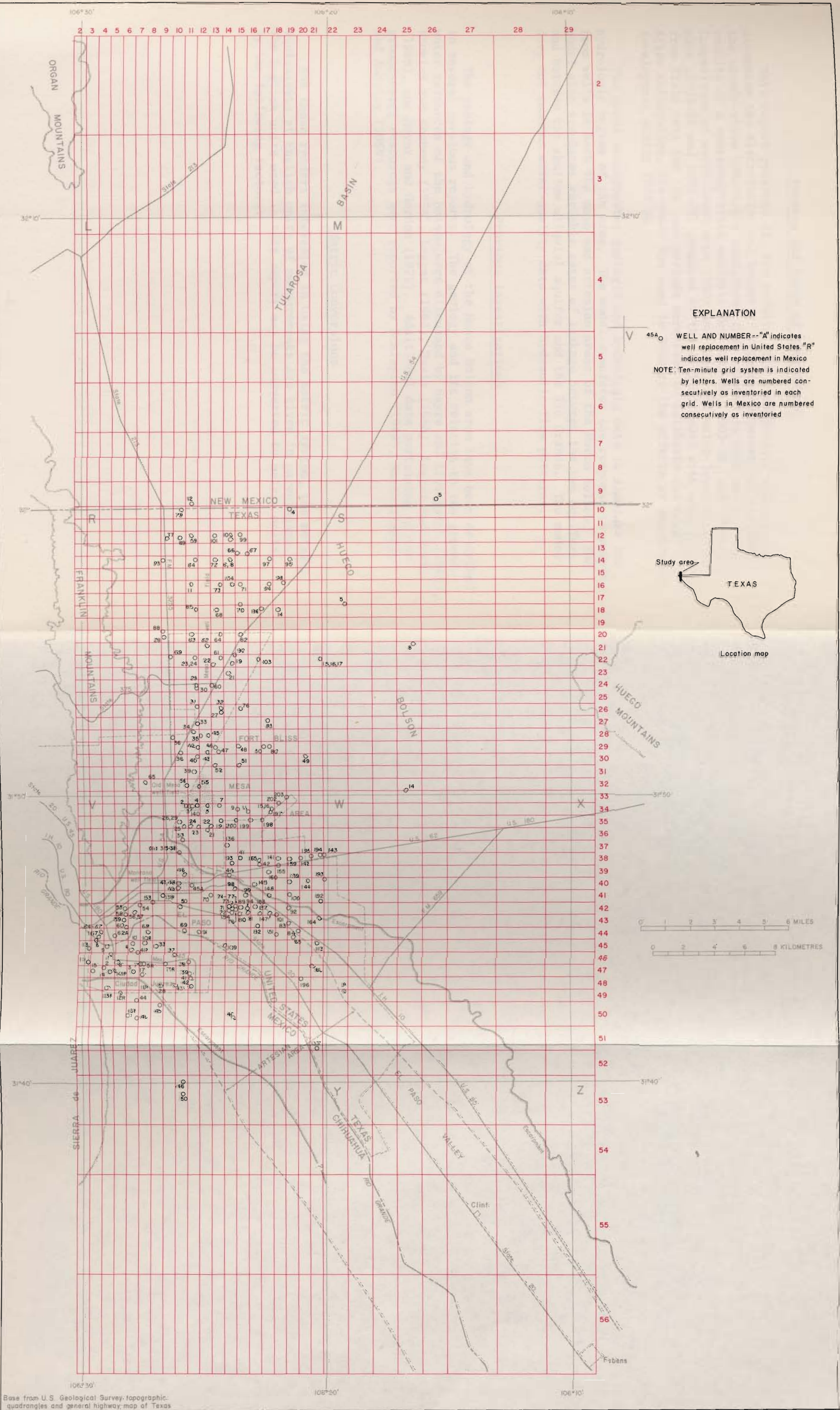

FIGURE 1.-Locations of wells and variable grid pattern used for modeling the northwestern half of the Hueco Bolson 
This report presents ( 1 ) the results of a steady-state analysis to determine the distribution and amount of recharge necessary to maintain the steady-state hydrologic conditions that existed in 1903 and (2) the results of a nonsteady-state analysis for 1903-36, 1903-58, and 1903-73. Comparisons of water-level maps (1903 and 1936) and water-level decline maps (1903-58 and 1903-73) produced by the digital model with maps prepared from field data for the same periods were used to calibrate the model. After calibration, the model was used to predict the effects of additional development during 1973-90.

The model incorporates geologic and hydrologic data to simulate the hydrologic regime of the area. The model simulates the response to pumping from wells in both the mesa and artesian areas of the Hueco Bolson. The model also simulates variable rates of leakage between the two aquifers and between the shallow alluvial aquifer and the Rio Grande. The model does not combine water-quality data with hydraulic-flow patterns.

\section{Previous Investigations}

The geology and hydrology of the Hueco Bolson area have been described in several previous reports. The geology and its relation to the groundwater resources of the bolson were discussed by Sayre and Livingston (1945), Knowles and Kennedy (1958), Leggat (1962), Davis (1965), Leggat and Davis (1966), and Meyer and Gordon (1972). Additional data pertaining to the ground-water resources were reported by Scalapino (1949), Smith (1956), and Audsley (1959).

\section{Metric Conversions}

For those readers interested in using the metric system, the metric equivalents of English units of measurements are given in parentheses. The English units used in this report may be converted to metric units by the following factors: 


\begin{tabular}{|c|c|c|c|c|}
\hline \multicolumn{2}{|c|}{ From } & \multirow{2}{*}{$\begin{array}{l}\text { Multiply } \\
\text { by }\end{array}$} & \multicolumn{2}{|l|}{ To obtain } \\
\hline Unit & $\begin{array}{l}\text { Abbrevi- } \\
\text { ation }\end{array}$ & & Unit & $\begin{array}{l}\text { Abbrevi- } \\
\text { ation }\end{array}$ \\
\hline acre-feet & -- & 0.001233 & cubic hectometres & $\mathrm{hm}^{3}$. \\
\hline $\begin{array}{l}\text { cubic feet } \\
\text { per second }\end{array}$ & $f t^{3} / \mathrm{s}$ & .02832 & $\begin{array}{l}\text { cubic metres } \\
\text { per secord }\end{array}$ & $\mathrm{m}^{3} / \mathrm{s}$ \\
\hline feet & -- & .3048 & metres & $\mathrm{m}$ \\
\hline $\begin{array}{l}\text { gallons per: } \\
\text { day per foot }\end{array}$ & $\mathrm{gal} / \mathrm{d} / \mathrm{ft}$ & .01245 & $\begin{array}{l}\text { metres squared } \\
\text { per day }\end{array}$ & $\mathrm{m}^{2} / \mathrm{d}$ \\
\hline $\begin{array}{l}\text { gallons per } \\
\text { minute }\end{array}$ & $\mathrm{gal} / \mathrm{min}$ & .003785 & $\begin{array}{l}\text { cubic metres } \\
\text { per minute }\end{array}$ & $\mathrm{m}^{3} / \mathrm{min}$ \\
\hline miles & -- & 1.609 & kilometres & $\mathrm{km}$ \\
\hline $\begin{array}{l}\text { million gallons } \\
\text { per day }\end{array}$ & million gal/d & .04381 & $\begin{array}{l}\text { cubic metres } \\
\text { per second }\end{array}$ & $\mathrm{m}^{3} / \mathrm{s}$ \\
\hline
\end{tabular}

\section{GEOHYDROIJGY OF THE HUECO BOLSON}

The sediments of the Hueco Bolson consist of unconsolidated deposits of interbedded sand, gravel, clay, and silt. Individual beds range in thickness from a few feet to about 100 feet $(30.5 \mathrm{~m})$, but most beds grade laterally or vertically into finer or coarser beds within short distances. Near the Franklin Mountains, the deposits are less than 100 feet $(30.5 \mathrm{~m})$ thick, but increase in thickness to a maximum of about 9,000 feet $(2,743$ m) approximately 4 miles $(6.4 \mathrm{~km})$ east of the Franklin Mountains. The thickness then decreases to about 500 feet $(152 \mathrm{~m})$ approximately 13 miles $(20.9 \mathrm{~km})$ east of the area of maximum thickness. The bedrock from the Franklin Mouritains to the point of maximum thickness is granite; east of this area, the bedrock is limestone (Mattick, 1967, p. D-90).

Ground water in the EI Paso area occurs in the unconsolidated deposits. of the Hueco Bolson and in the alluvium of the Rio Grande. In the bolson deposits, the ground water is under water-table conditions in the mesa part of the bolson, which is that part extending roughly from the escarpment at the northern edge of the El Paso Valley northward into New Mexico. South of the mesa and underlying nearly the whole of the El Paso Valley, including nearly all Ciudad Juarez, the ground water occurs under artesian conditions. The bolson deposits (bolson aquifer) which is the principal source of water in the El Paso area, is layer 2 in the digital model. Ground water also, occurs under water-table conditions in the shallow alluvium of the Rio Grande. These deposits, which are referred to as the shallow alluvium or alluvial aquifer, are modeled as layer 1. 
The unconsolidated deposits in the bolson contain fresh water that has less than $1,000 \mathrm{mg} / 1$ (milligrams per litre) dissolved solids and saline water that has more than $1,000 \mathrm{mg} / 1$ dissolved solids. The fresh water occurs, in a trough of irregular depth and width, the axis of which is 2 to 4 miles $(3.2$ to $6.4 \mathrm{~km})$ east of the Frankin Mountains.

\section{Ground-Water Recharge, Movement, and Discharge}

Ground-water recharge to the deposits of the Hueco Bolson occurs principally by the infiltration of runoff along the base of the Organ and liranklin Mountains in New Mexico and Texas and the Sierra de Juarez in Mexico. Ground water in the Texas part of the bolson moves generally southward except in local areas where the hydraulic gradients have been altered by heavy pumping. The water moves from the mesa (water-table) area to the irtesian area, where it becomes confined beneath beds of low permeability. lhe artesian head is maintained by the higher altitude of the water surface in the mesa area. In Mexico, the general direction of ground-water flow is from south to north; and part of the flow is in the direction of the IJ.S. border (Secretario de Recursos Hidraulicos, personal commun., 1974).

Prior to development, discharge occurred in the artesian area by upward movement of water into the alluvium and then into the Rio Grande. The largest amount of discharge from the bolson deposits is now by pumping from wells. Because of heavy pumping in the artesian area, on both the American and Mexican sides of the river, the direction of vertical movement of ground water has been reversed in recent years in the vicinity of. El l'aso and Ciudad Juarez. The water now moves downward from the alluvium to the bolson deposits, and seepage from the Rio Grande recharges the alluvium. When a section of the Rio Grande was lined with concrete in 1968 , seepage to the alluvium stopped, but leakage from the: shallow alluvium to the deeper bolson deposits continued; and water levels declined in the alluvial aquifer adjacent to the lined section of the river.

\section{Changes in Water Levels}

Prior to 1904, the municipal water supply for El Paso was obtained from the Rio Grande and from shallow wells in the alluvium. In 1904 , the U.S. Axmy and the city of EI Paso began drilling deeper wells in the vicinity of Fort Bliss. The amount of water pumped from these wells is not known, although it undoubtedly was sma11. By 1906, 1.2 million gal/d $\left.10.05 \mathrm{~m}^{3} / \mathrm{s}\right)$ was pumped for all purposes from deep wells in the bolson leposits; and since that time, the amount of ground water pumped has increased steadily. According to available records, 2.07 million acre-feet $(2,552$ $\mathrm{hm}^{3}$ ) of water has been pumped since 1903 (fig. 2). 


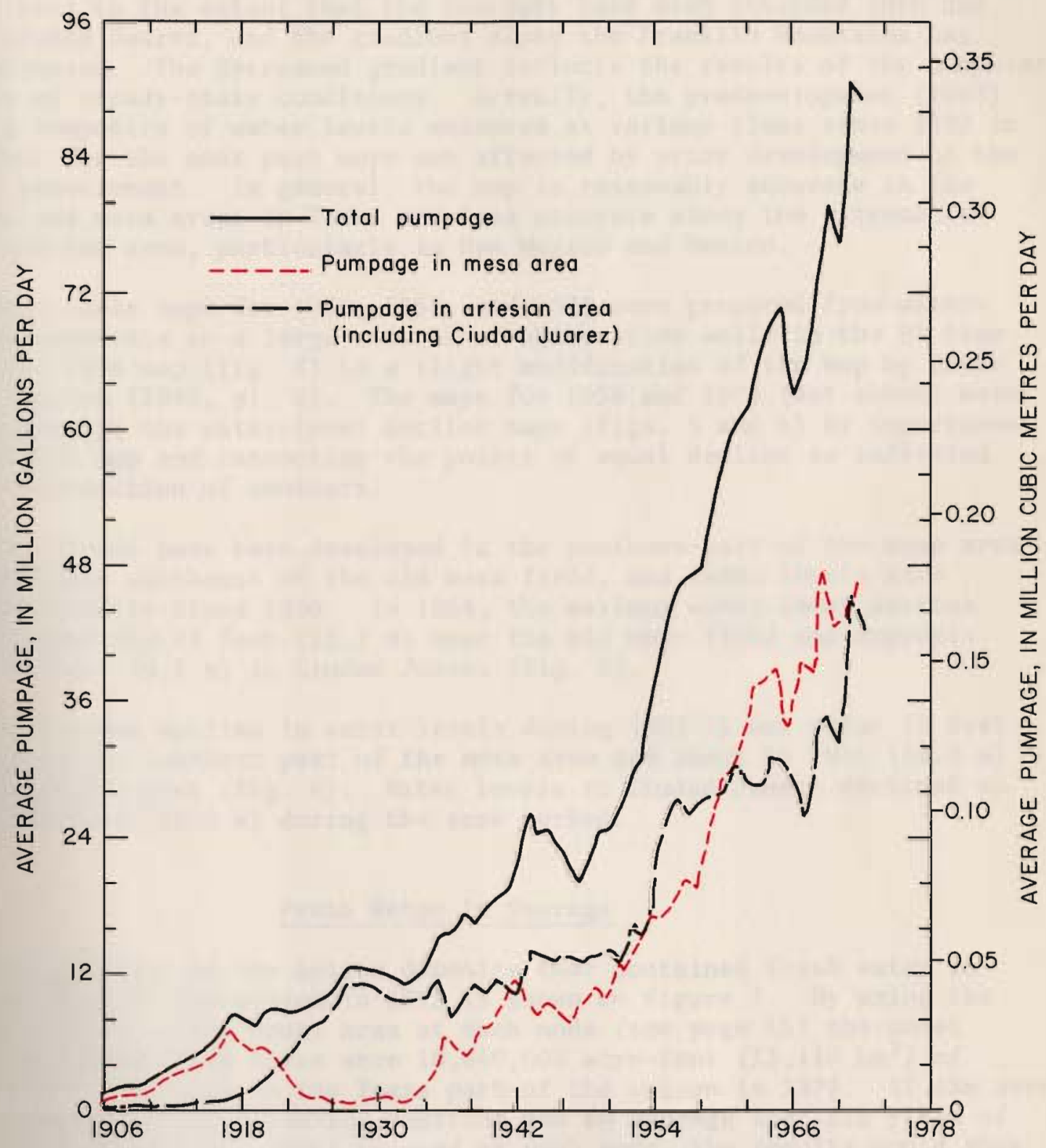

FIGURE 2. - Estimated average daily pumpage from deep wells in the Hueco Bolson, 1906-73 
The configuration of the ground-water surface in the Hueco Bolson in 1903 (prior to ground-water development) is shown on figure 3 . The map is a modification by Meyer and Gordon (1972, fig. 8) of the map by Leggat and Davis (1966) to the extent that the contours have been extended into and beyond Ciudad Juarez, and the gradient along the Franklin Mountains has been decreased. The decreased gradient reflects the results of the computer analyses of steady-state conditions. Actually, the predevelopment (1903) map is a composite of water levels measured at various times since 1903 in wells that for the most part were not affected by prior development at the time of measurement. In general, the map is reasonably accurate in the artesian and mesa areas in Texas and less accurate along the extremities of the modeled area, particularly in New Mexico and Mexico.

Water-table maps for 1936,1958 , and 1973 were prepared from waterlevel measurements in a large network of observation wells in the E1 Paso area. The 1936 map (fig. 4) is a slight modification of the map by Sayre and Livingston (1945, pl. 2). The maps for 1958 and 1973 (not shown) were used to prepare the water-level decline maps (figs. 5 and 6) by superimposing the 1903 map and connecting the points of equal decline as indicated by the intersection of contours.

Well fields have been developed in the southern part ' of the mesa area both north and southeast of the old mesa field, and water levels have declined steadily since 1936. In 1958, the maximum water-level decline was approximately 45 feet $(13.7 \mathrm{~m})$ near the old mesa field and approximately 30 . feet $(9.1 \mathrm{~m})$ in Ciudad Juarez (fig. 5).

The maximum decline in water levels during 1903-73 was about 70 feet $(21.3 \mathrm{~m})$ in the southern part of the mesa area and about 59 feet $(18.0 \mathrm{~m})$ in the northern part (fig. 6). Water levels in Ciudad Juarez declined as much as 74 feet $(22.6 \mathrm{~m})$ during the same period.

\section{Fresh Water in Storage}

The thickness of the bolson deposits that contained fresh water in the Texas part of the bolson in 1973 is shown on figure 7 . By using the specific yield for the nodal area at each node (see page 15) the model calculation shows that there were $10,640,000$ acre-feet $\left(13,119 \mathrm{hm}^{3}\right)$ of fresh water in storage in the Texas part of the bolson in 1973. If the area used in the calculation remains constant and an. average specific yield of 0.15 (Leggat and Davis, 1966) is used at each node, the results would show $8.60 \mathrm{milli}$ ion acre-feet $\left(10,604 \mathrm{hm}^{3}\right)$ of fresh water in storage. 


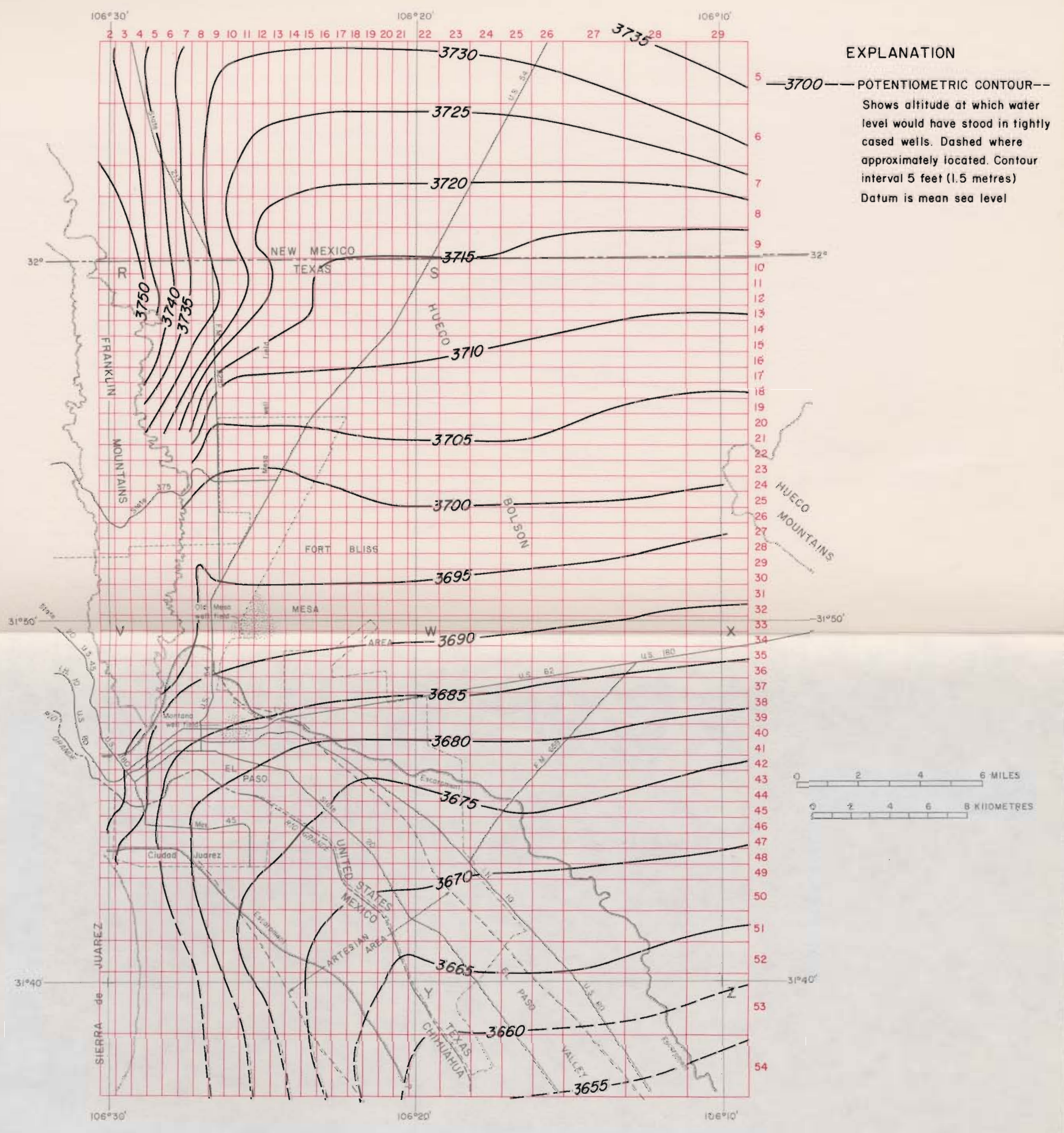


EXPLANATION

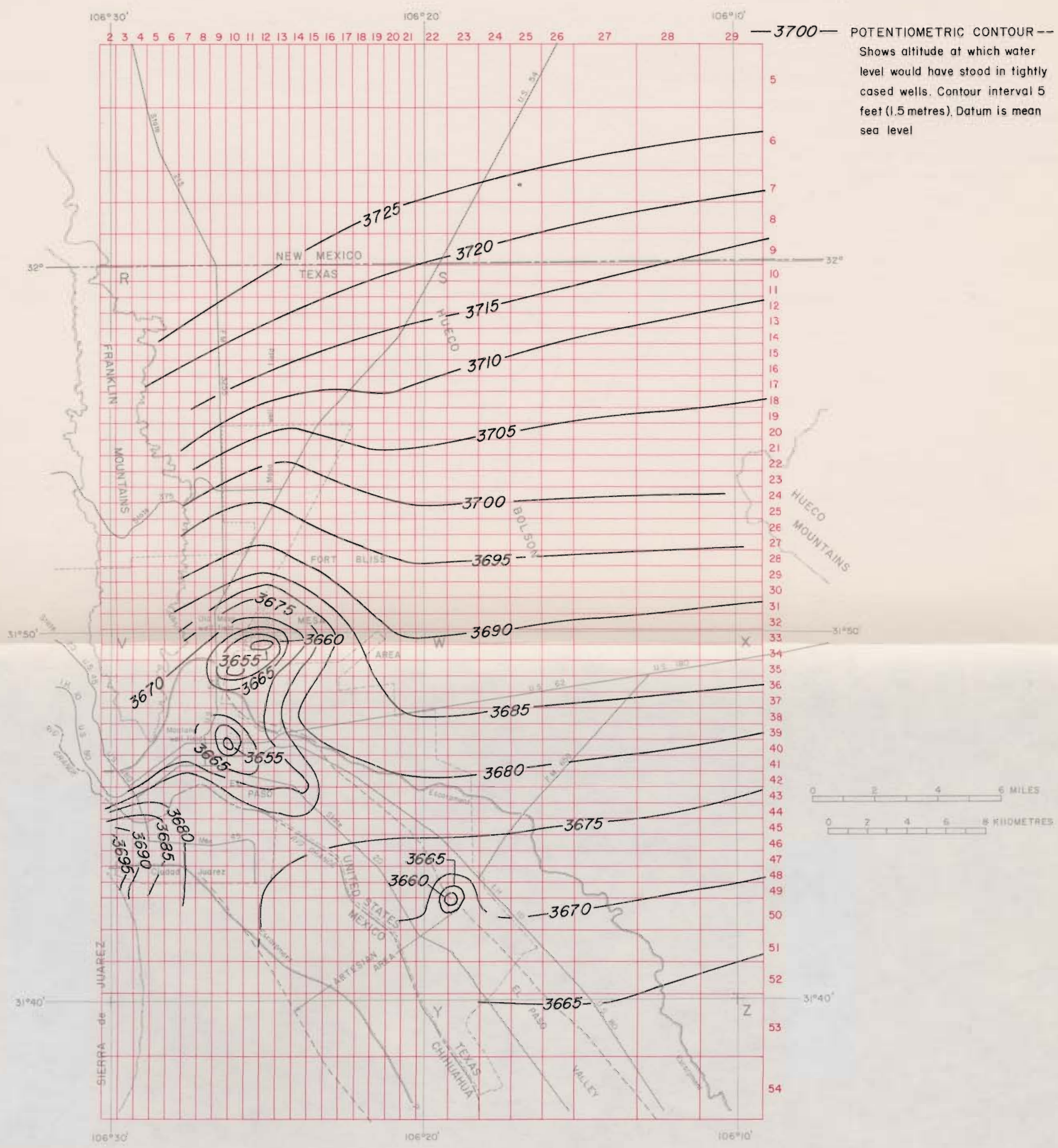




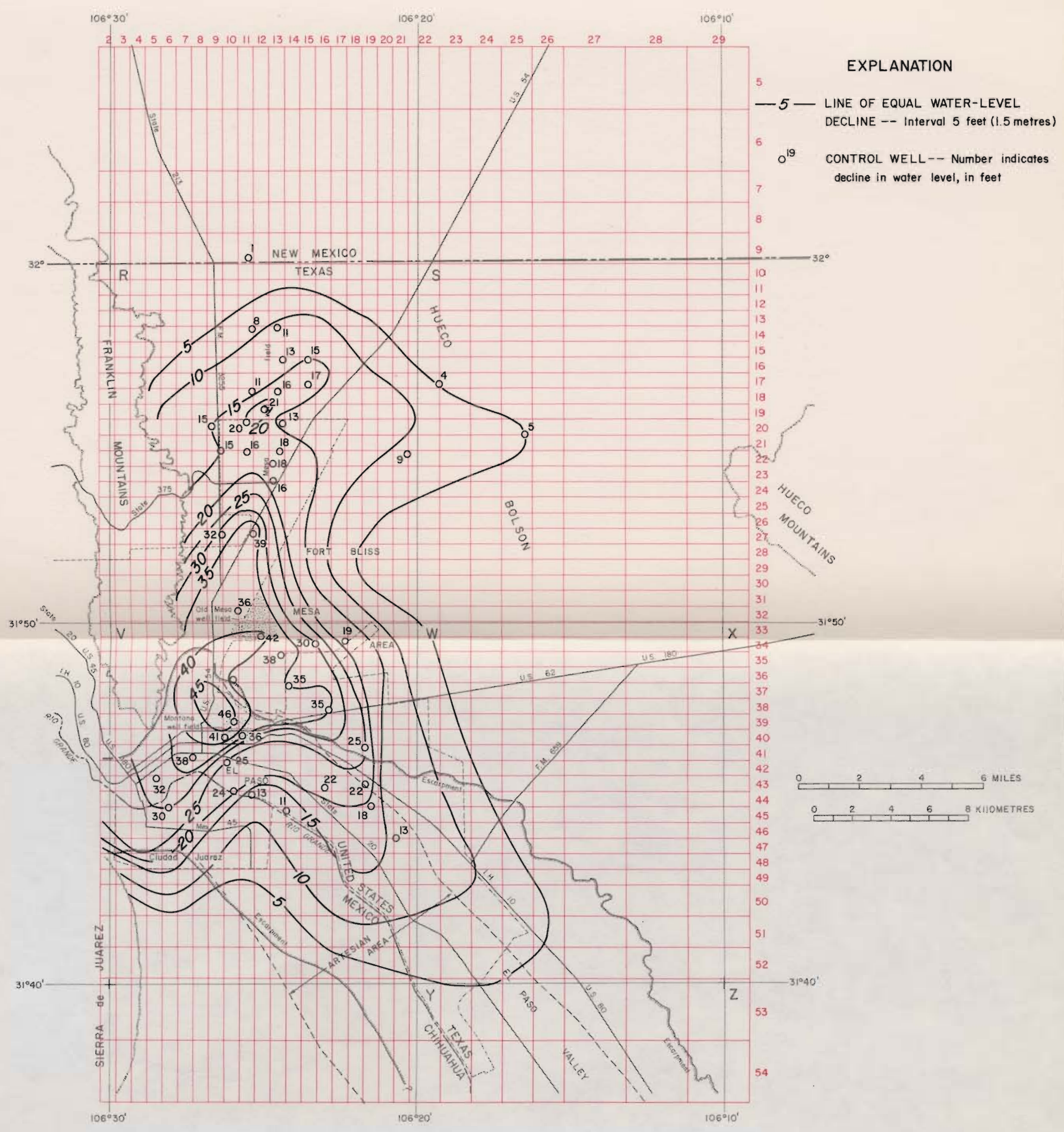




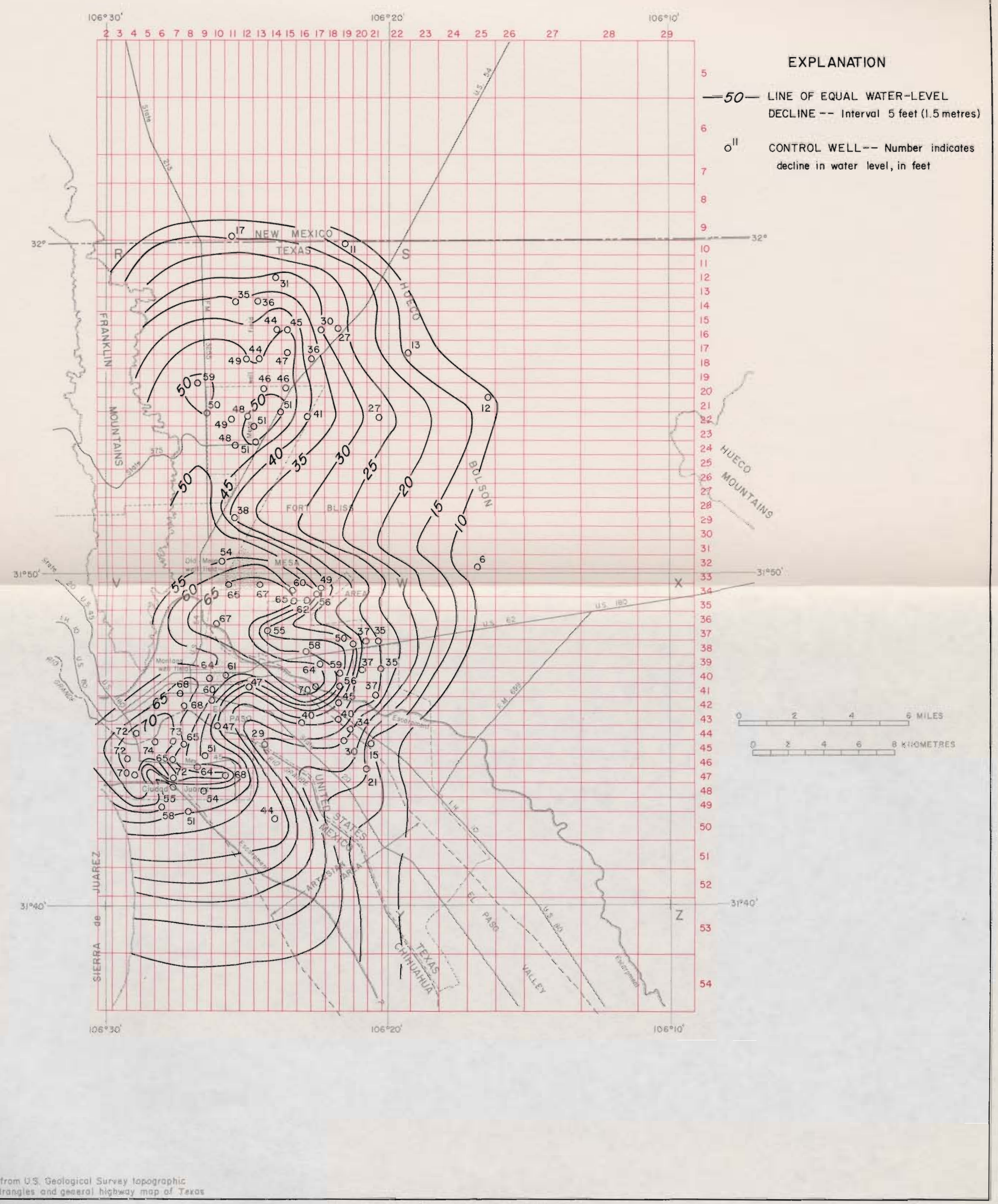

FIGURE 6. - Approximate decline in water levels, 1903-73 


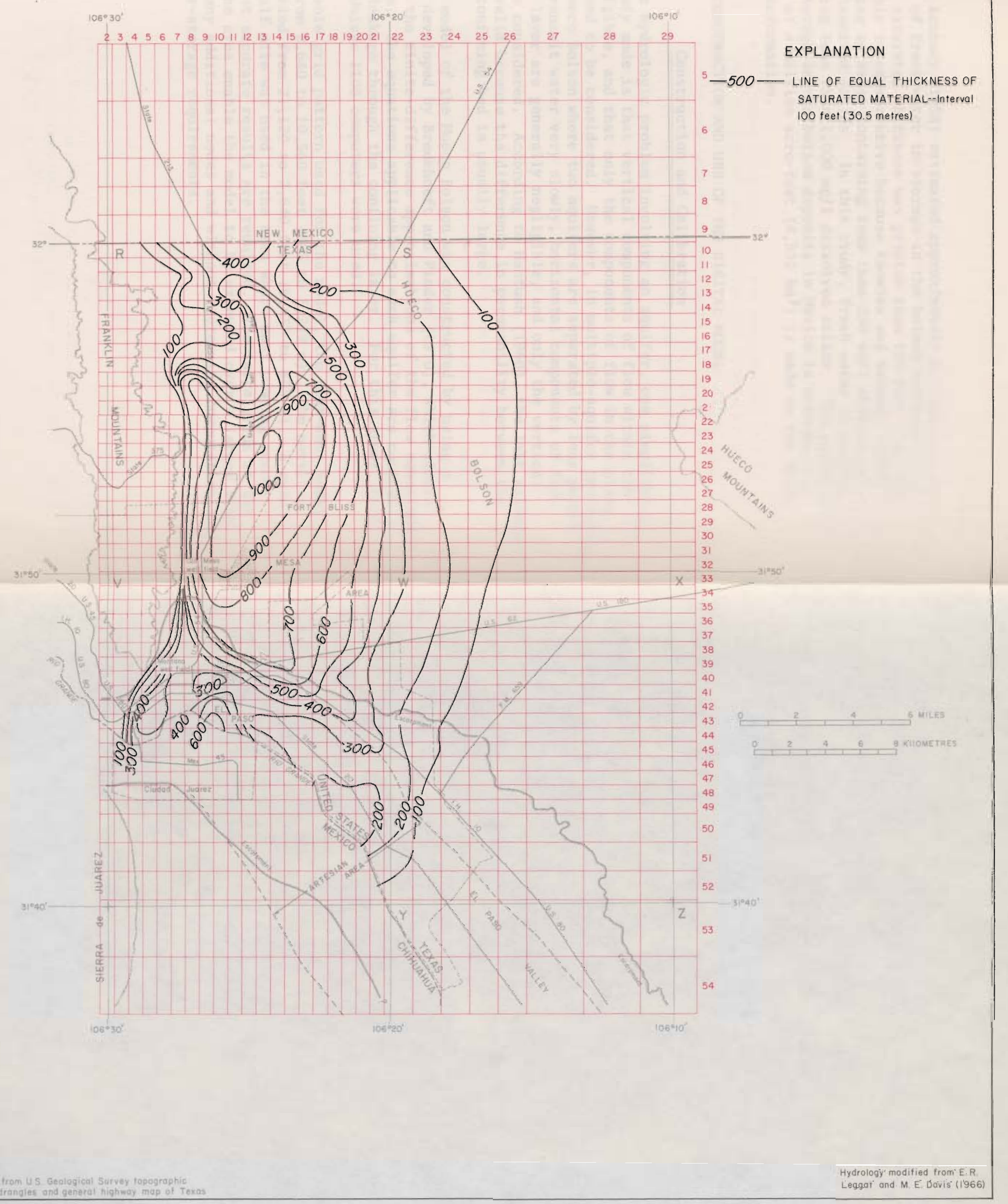


Knowles and Kennedy (1958) estimated approximately 6.2 million acrefeet $\left(7,645 \mathrm{hm}^{3}\right)$ of fresh water in storage in the boison deposits in New Mexico where the saturated thickness was greater than 100 feet $(30.5 \mathrm{~m})$. This value probably is conservative because Knowles and. Kennedy (1958) defined fresh water as water containing less than $250 \mathrm{mg} / 1$ chloride or about $700 \mathrm{mg} / 1$ dissolved solids. In this study, fresh water is defined as water containing less than $1,000 \mathrm{mg} / \mathrm{l}$ dissolved solids. The amount of fresh water in storage in the bolson deposics in Mexico is unknown, but an approximation of 4 million acre-feet $\left(4,932 \mathrm{hm}^{3}\right)$ is made on the basis of very limited information.

\section{CONSTRUCTION AND USE OF. THE DIGITAL MODEL}

\section{Construction and Calibration}

In solving a hydrologic problen involving an aquifer, one simplifying assumption commonly made is that yertical components of flow within the aquifer are negligible, and that only the components of flow in the plane of the aquifer need to be considered. However, in multiple-aquifer problems, such as in the Hueco. Bolson where two aquifers are separated by less permeable beds that transmit water very slowly, horizontal components of flow in the confining layer are generaily negligible, and only the vertical component need be considered. Acconding to Hantush (1950), the Iast assumption is usually valid because the difference in permeability between the aquifer and the confining bed is usually large.

The digital model of the Hueco Bolson was constructed by using a computex program developed by Bredehoeft and Pinder (1970), which simultaneously solves the finite-difference approxinations of the flow equations for both aquifers. The equations applicable to each aquifer are coupled by the vertical leakage through the confining layer. For this study, both the IBM 360 and Univac 1108 computers were used.

In the variable grid pattern used for the model, the east-west nodal spacing varied from 2,640 to 10,560 feet ( 805 to $3,219 \mathrm{~m}$ ). The northsouth spacing varied from 21,120 to 2,640 feet $(6,437$ to $805 \mathrm{~m})$. A grid spacing of one-half mile was used ir tre area where nost pumping.occurs and where the most accurate results are required. The large grids at the extremities of the area enable the mode to be extended over a larger area without adiding many additionai nodes and without increasing computation time and computex-storage requirements. 
The following parameters were entered in the model at each node: (1) The altitude of the initial (1903) head in the aquifer; (2) the transmissivity; $1 /$ and (3) the specific yield (or storage coefficient) for the nodal area for each aquifer. The following parameters were entered at the appropriate node: (1) The vertical hydraulic conductivity between the river and the alluvium and between the alluvium and the bolson deposits; (2) pumpage; (3) recharge along the model boundaries; and (4) the position and elevation of the constant-head boundary that simulates the effect of the Rio Grande.

A map of regional transmissivity (fig. 8) was constructed on the basis of aquifer-test data and the assumption that the transmissivity at some nodes was equal to the product of saturated thickness and average hydraulic conductivity. The map generally represents the areal pattern of transmissivity in the fresh-water section of the bolson deposits, and shows that the transmissivities range from about $10,000 \mathrm{ga} / \mathrm{d} / \mathrm{ft}\left(124 \mathrm{~m}^{2} / \mathrm{d}\right)$, principally along the northern boundary, to about $280,000 \mathrm{gal} / \mathrm{d} / \mathrm{ft}(3,486$ $\mathrm{m}^{2} / \mathrm{d}$ ). An average transmissivity of $30 ; 000 \mathrm{gal} / \mathrm{d} / \mathrm{ft}\left(374 \mathrm{~m}^{2} / \mathrm{d}\right)$ was estimated for the alluvium in the Rio Grande Valley. The specific yield of the unconfined bolson deposits ranges from 0.10 to 0.30 . The specific yield of the alluvium is 0.20. The storage coefficient of the bolson deposits in the artesian area ranges from 0.0001 to 0.0004 . The specific yield (and the coefficient of storage) is not a function of time.

Recharge was introduced at the mountain fronts along the western boundary of the area modeled (including the Sierra Juarez in Mexico and the Organ Mountains in New Mexico) and along the northern boundary to account for inflow from the northern part of the Hueco Bolson and the southern part of the Tularosa Basin in New Mexico. The eastern and southern boundaries, however, were assumed to be impermeable with no recharge. Along the Rio Grande, vertical seepage was allowed to occur between the river and the alluvium at al1 nodes crossed by the river. The model also accounts for the lining of part of the river channel in September 1968. The vertical hydraulic conductivity along the lined reach is set to zero, thus eliminating vertical leakage at that time. Pumpage was entered into the model by obtaining the average discharge of all wells in a nodal area for each of nine pumping periods, 1903-19,1920-35,1936-47,1948-52,1953-57,1958$62,1963-67,1968-72$, and 1973-90.

\footnotetext{
I/ For the convenience of compatibility with the previous model studies, values of transmissivity are expressed in gallons per day per foot. To convert to feet squared per day, multiply by 0.134 .
} 
EXPLANATION

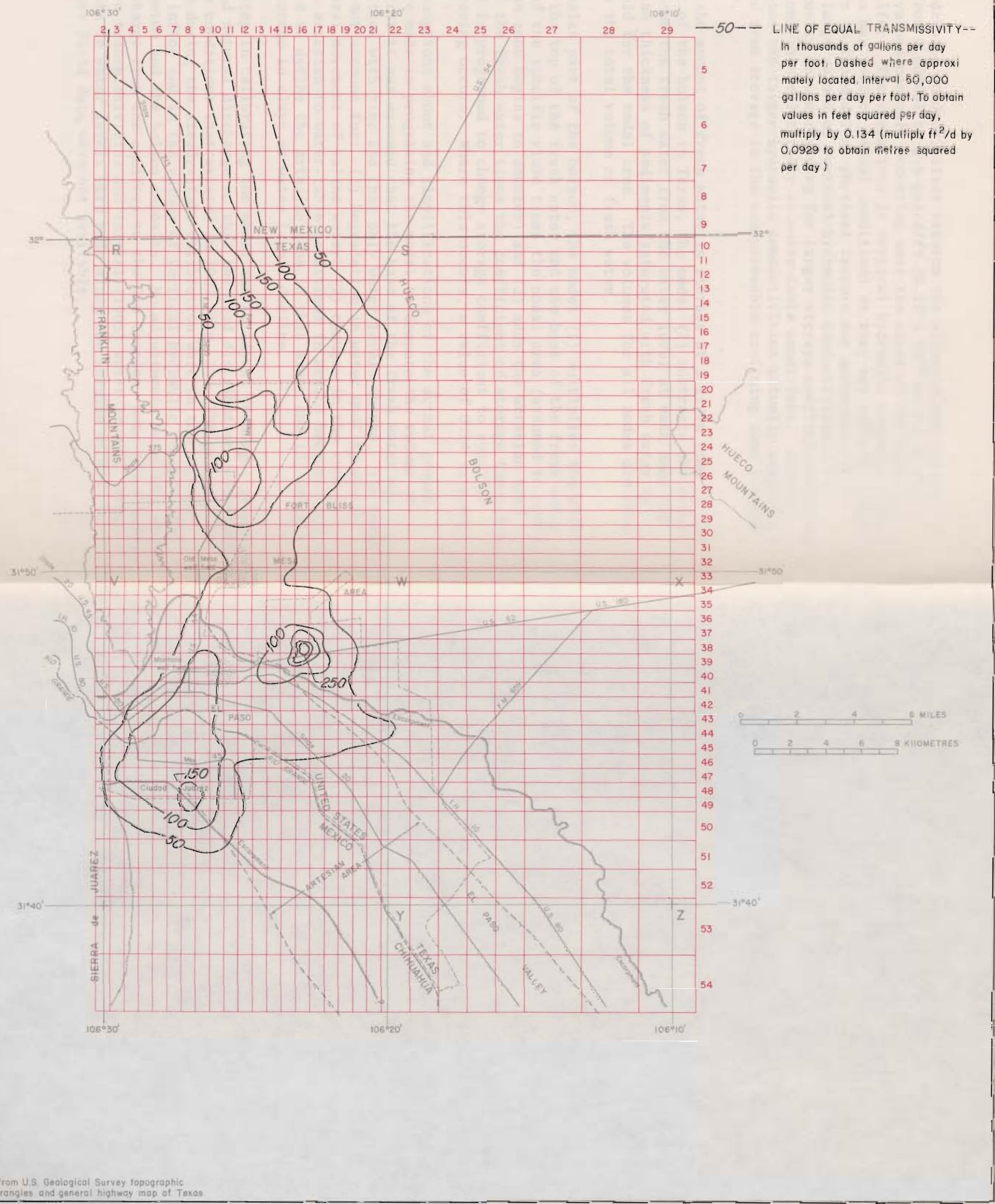


Vertical "hydraulic conductivities between the alluvium and bolson deposits range from 0.000001 to $9.5 \mathrm{gal} / \mathrm{d} / \mathrm{ft}\left(0.12 \times 10^{-8}\right.$ to $\left.0.118^{\prime} \mathrm{m}^{2} \% \mathrm{~d}\right)$, with the higher values commonly occurring near the edges of the confined' parts of the aquifer. The variations in vertical hydraulic conductivities at adjacent nodes may reflect actual conditions or they may reflect compensation for errors in the model or physical factors not accounted for in the model: The large values of vertical hydraulic conductivities, for example, may actually be compensating for larger storage coefficients where artesian conditions change laterally to water-table conditions. Another possibility is that the larger hydraulic conductivities actually compensate for water derived from storage in the semipermeable confining zone between the two aquifers.

To compute the amount of fresh water in storage at a given time in the nonartesian part of the bolson in Texas, the model (1) subtracts the elevation of the base of the fresh water from the water level at each node and. (2) multiplies the thickness of sediments saturated with fresh water by the specific yield for the nodal area. The volumes for all nodes are then summed to obtain the total volume of fresh water.

In the artesian part of the bolson, the model (1) multiplies the dif-. ference between the top of the fresh water and the base of the fresh water by an estimate of the specific yield times the nodal area (assumed to apply when the artesian zone begins to dewater) and (2) adds the artesian head above the top of the fresh water times the coefficient of storage times the area. The model is programed to change storage coefficient to specific yield when dewatering occurs. Where this occurs, a value of 0.14 is used.

Several assumptions about and simplifications of the actual groundwater system were made in programing the model to compute the volume of fresh water. First it was assumed that the base of the fresh water was constant in position with time and that only water levels change. The model computations do not account for: (1) Degradation. in water quality due to vertical or lateral movement of saline water; (2) changes in the storage coefficient from artesian to water-table conditions in Mexico because data are not available to define the artesian zone in this area; and (3) water released from storage in clays as water levels decline:

The first step in calibrating the model was to adjust recharge, groundwater inflow, and natural discharge so that the head distribution reproduced the steady-state conditions that existed in 1903 (fig. 3). The primary adjustments made during the steady-state calibration were in the volumes of recharge and inflow and in the values of vertical hydraulic conductivity between the alluvium and the bolson deposits. No adjustments were made to the natural discharge from the aquifers to the Rio Grande. Some adjustments were also made in transmissivities and initial (1903) water levels. Most of the adjustments in water levels were made along the margins of the modeled area where field data were not available. 
Figure 3 shows the water levels in 1903 as determined from historical records, and figure 9 shows the water levels in 1903 as computed by the model.

In genera1, the computed 1903 map (fig. 9) closely approximates the 1903 map (fig. 3) as determined from historical records, except along the northern margin of the Franklin Mountains. In this area (columns 2 to 8 and rows 2 to 18 ), the computed hydraulic gradient is considerably less than that shown on figure 3 , and the computed water levels are from 1 to 24 feet $(0.3$ to $7.3 \mathrm{~m})$ lower than the historical levels. The differences are greater along the steeply dipping slopes of the Franklin Mountains where well data are not available. Eastward, in an area. that includes columns 8 to 19 and rows 5 to 31 , the computed water levels range from about 1 to 7 feet $(0.3$ to $2.1 \mathrm{~m}$ ) higher than the historical levels. Further adjustments to the values of recharge and transmissivity would have resulted in a closer agreement of the two maps; but because the agreement seemed reasonable in the area where most of the development has and will take place, the adjustment process was ended.

The recharge rate as determined by the mode1 is $7.79 \mathrm{ft}^{3} / \mathrm{s}\left(0.22 \mathrm{~m}^{3} / \mathrm{s}\right)$ or 5,640 acre-feet $\left(7.0 \mathrm{hm}^{3}\right)$ per year, which is about 40 percent of the amount estimated by Sayre and Livingston (1945). This does not include recharge from the Rio Grande to the alluvium (layer 1 of the model) nor recharge from the alluvium to the bolson (layer 2 of the mode1). The model also revealed that the average specific yield is 0.1856 , which is somewhat greater than previously estimated (0.15). See Leggat and Davis (1966).

The second step in calibrating the model was to simulate pumping during the first eight historical periods (page 15) and to compare the computed results with the historical water-level data. The model was modified and tested mainly by altering the vertical hydraulic conductivity near the river and the specific yield near Fort Bliss until the recorded data were adequately simulated. Although transmissivity values in and near the Fort Bliss area were modified, the effect was moderate because of the insensitivity of the model to changes in transmissivity. Also, the transmissivity at a node, which was assumed to remain constant over a given period, was not corrected by the change in saturated thickness. The model is very sensitive to changes in values for recharge and discharge, but these parameters were not altered after:steady-state conditions were adequately simulated.

The model was calibrated for the altitude of the water surface in 1936 and for the changes in water levels for 1903-58 and 1903-73. The map of simulated water levels for January 1936 (fig. 10) compares reasonably well with the water-level map for June 1936 (fig. 4), except in the area near the old mesa well field and at Fort Bliss, where the historical map shows two cones of depression that were not reproduced accurately by the model. This discrepancy is due largely to the fact that the historical map was based on water levels measured in June, when the effects of seasonal pumping is near the maximum. Seasonal pumping changes are not included in this analysis. 


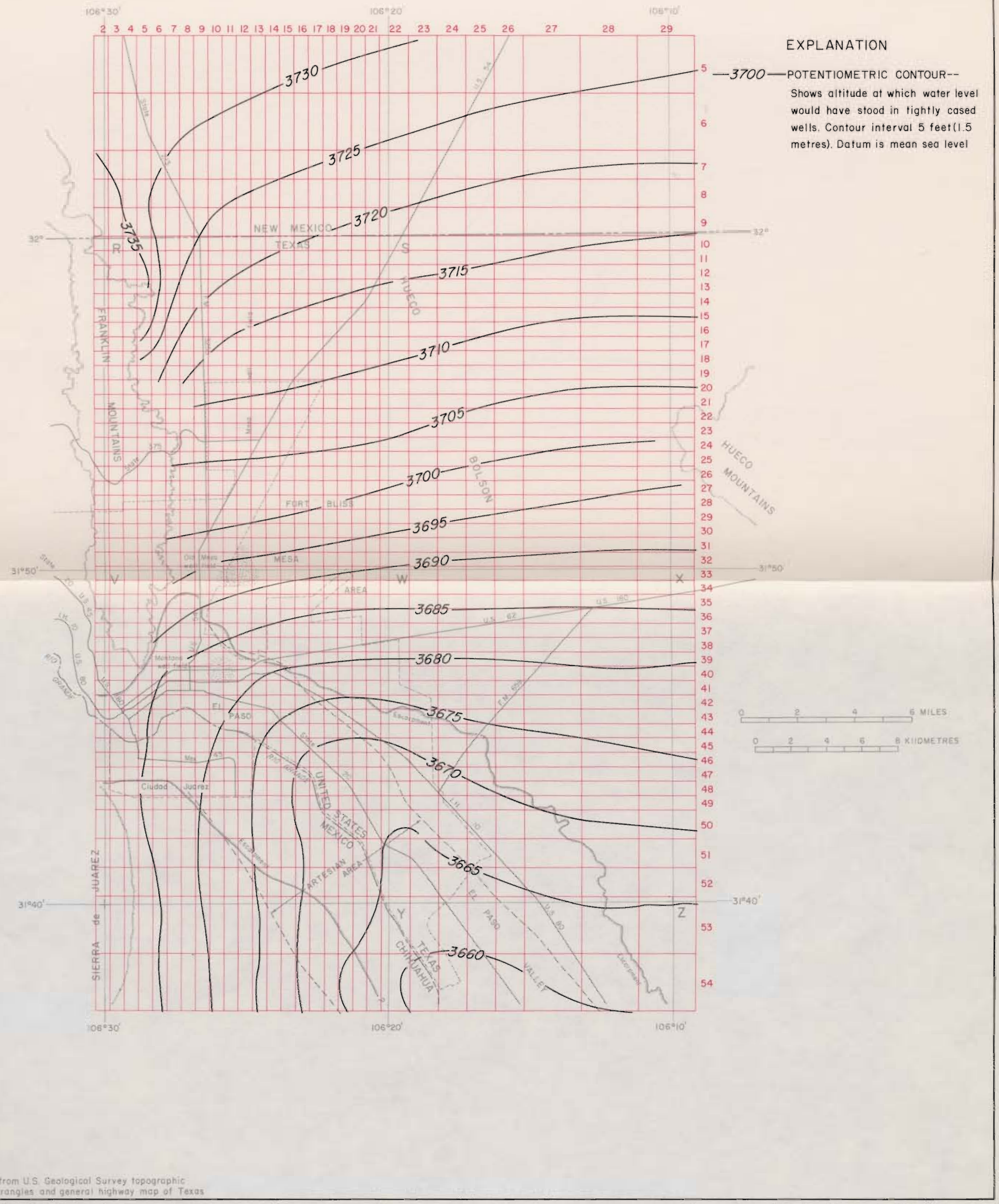




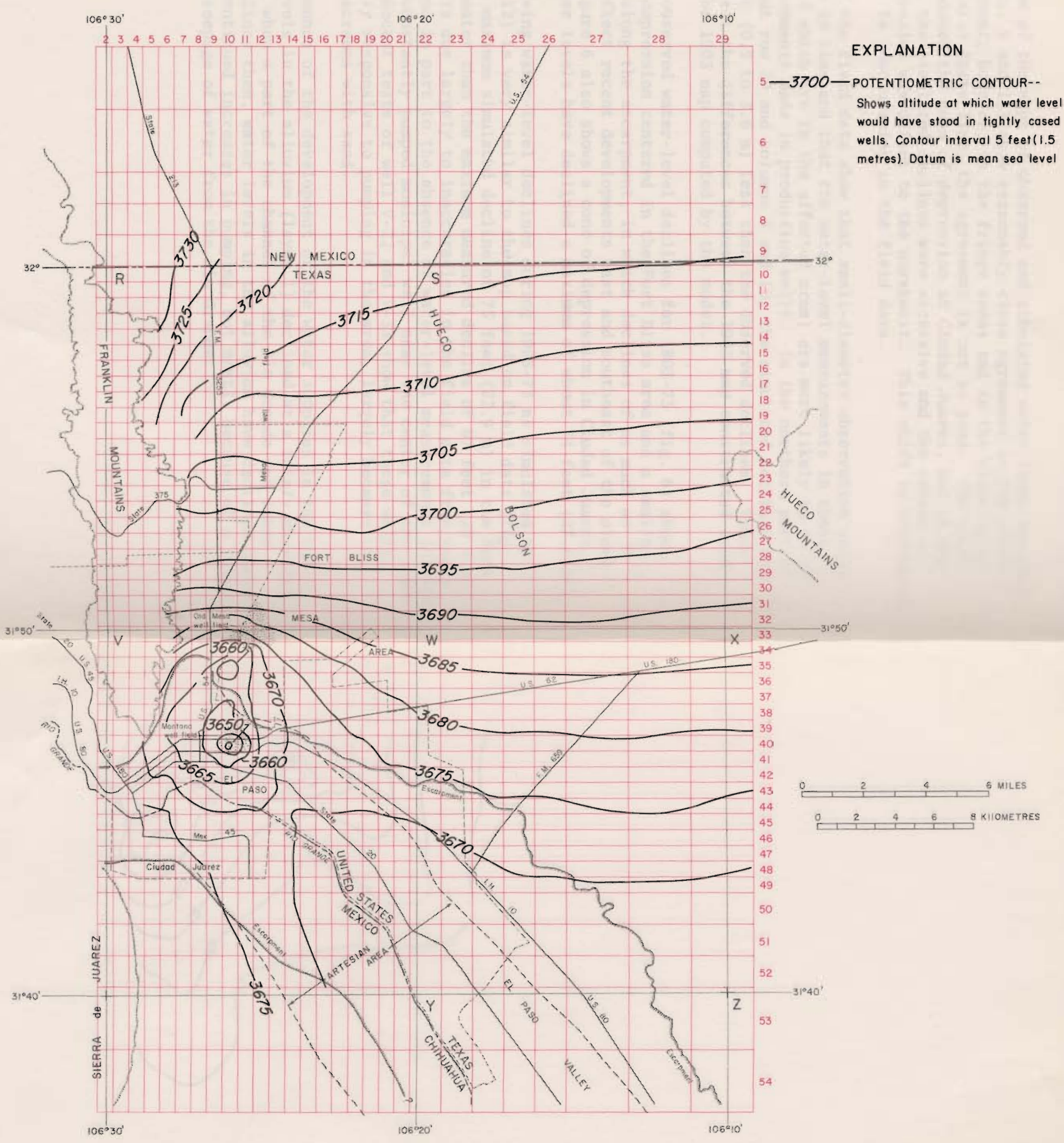


A comparison of the maps of observed and simulated water-level declines for 1903-58 (figs. 5 and 11) show reasonably close agreement in the areas. of older development; however, in the fringe areas and in the vicinity of the Texas-New Mexico State line, the agreement is not as good. The model accurately reproduced the cone of depression at Ciudad Juarez, but in the Fort Bliss area, the simulated declines were excessive and the center of the cone of depression was offset to the northeast. This shift is attributed at least in part to inaccuracies in the field data.

Analyses of the field data show that small-diameter observation wells become silted up in time and that the water-level measurements in these wells (several of which are in the affected area) are more 1 ikely to be in error than measurements made in production wells. In the northern part of the area, at about row 20 and columins 9 and 10 , the simulated declines are from 3 to 12 feet $(0.9$ to $3.6 \mathrm{~m})$ less than the observed declines. These differences reflect the differences between the 1903 map constructed from field data and the 1903 map computed by the model.

The map of observed water-level declines for 1903-73 (fig. 6) shows a large cone of depression centered in the Fort Bliss area and a smaller but deeper cone along the escarpment, in which declines of as much as 70 feet $(21.3 \mathrm{~m})$ reflect recent developments east and southeast of the older well fields. Figure 6 also shows a cone of depression in Ciudad Juarez, in which the water levels have declined a maximum of about 74 feet $(22.6 \mathrm{~m})$.

The map showing water-level declines during $1903-73$ as simulated by the model (fig. 12) is very similar to the map based on field data (fig. 6), although the maximum simulated decline of 75 feet $(22.9 \mathrm{~m})$ in the Fort Bliss area is greater than the maximum measured decline of 67 feet $(20.4 \mathrm{~m})$. This difference is due largely to inaccuracies in the field data from wells $\mathrm{V}-33$ and $\mathrm{V}-22$, and in part to the absence of water-level measurements in well $\mathrm{V}-19$, an almost constant1y pumped municipal wel1 near the center of the cone of depression. Recent tests of we11 V-22 and V-33 show that these wells are only partially responsive to pumping in the area, largely because of clogging of the screens with sand.

As a consequence of the development of the water supplies in the Hueco Bolson, water levels in the alluvium (layer 1) declined at a fairly moderate rate until 1968, when a part of the channel of the Rio Grande was lined with concrete. Since then, water levels in the alluvium have declined sharply; due in part to continued increases in pumping, but mostly. because of a sharp decrease in the seepage of water from the Rio Grande. 


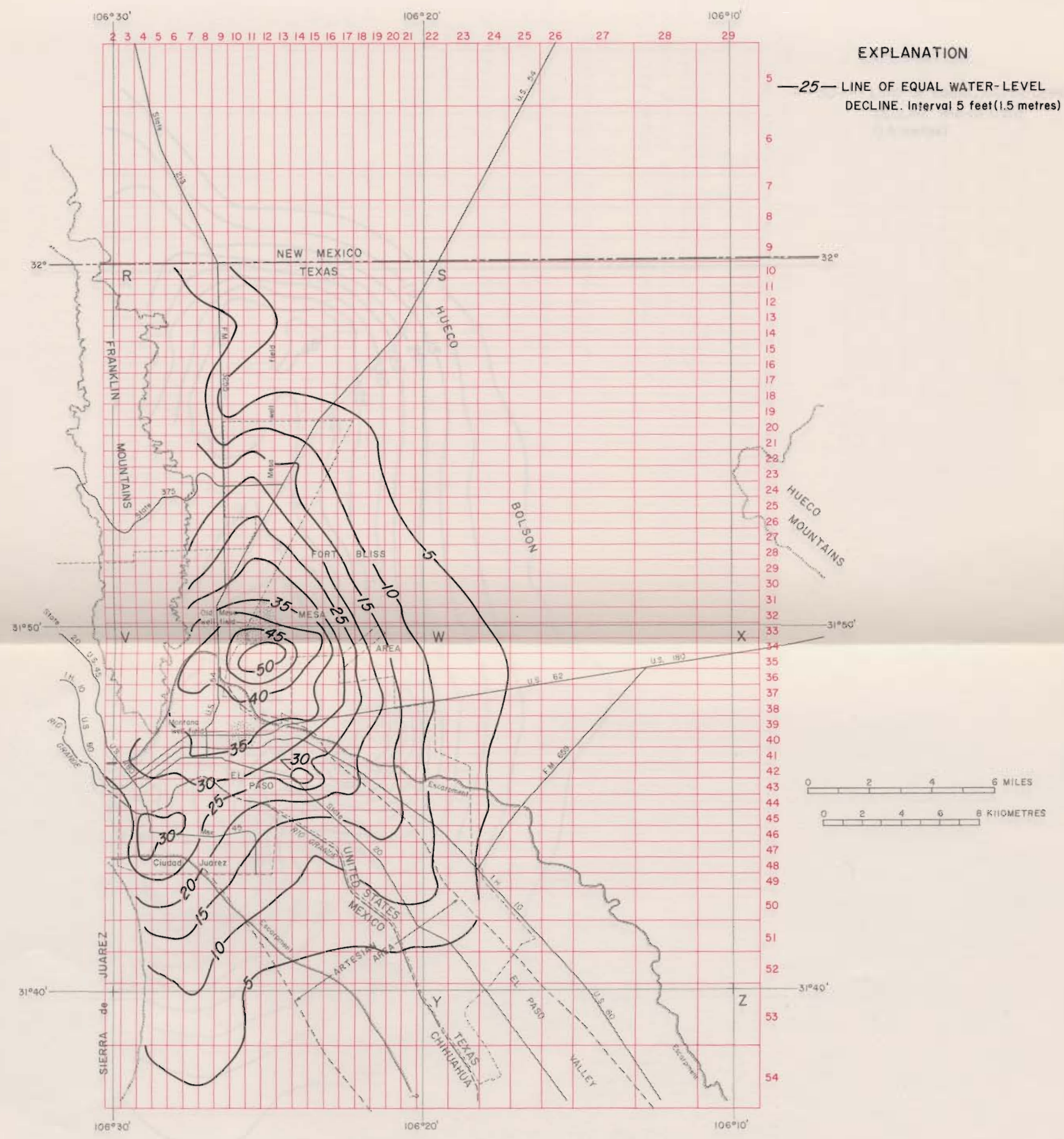




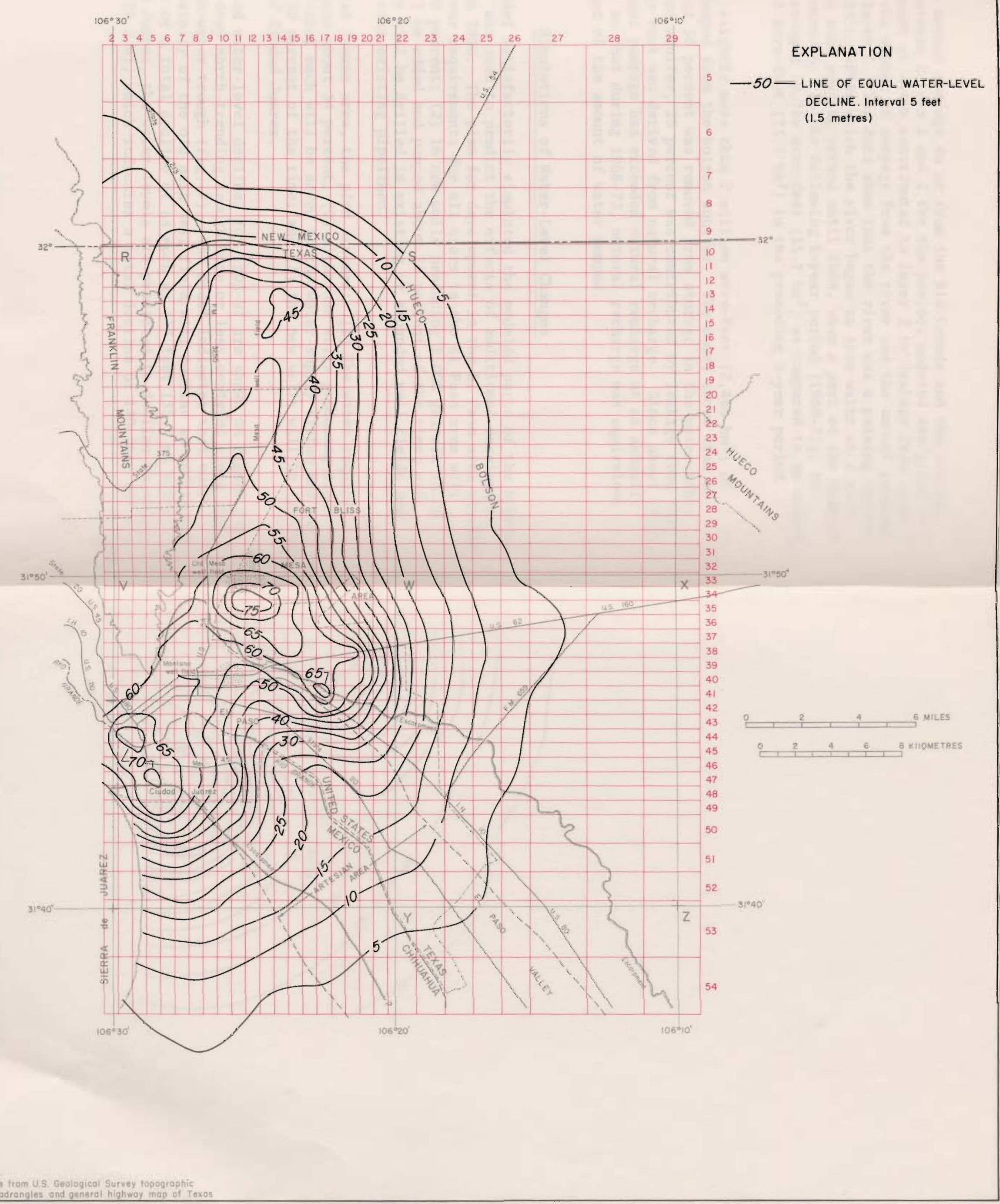

FIGURE 12. - Decline in water levels for $1903-73$ as computed by the digital model 
The average annual seepage to or from the Rio Grande and the average annual leakage between layers 1 and 2 for the periods modeled are given in table 1. The amount of water contributed to layer 2 by leakage from layer 1 is the sum of the amount of seepage from the river and the amount removed from storage in layer 1 . The data show that the river was a gaining stream until the mid-1930's, after which the river began to lose water at a rate that increased in each pumping period until 1968, when a part of the channel was lined with concrete. In the following 5-year period (1968-73), the annual. seepage averaged 12,765 acre-feet $\left(15.7 \mathrm{hm}^{3}\right)$ as compared to an annual average of 19,183 acre-feet $\left(23.7 \mathrm{hm}^{3}\right)$ in the preceding 5 -year period $(1963-68)$.

Since 1903 , slightly more than 2 million acre-feet $\left(2,466 \mathrm{hm}^{3}\right)$ of water has been pumped from the bolson aquifer. The mode1 shows that of this amount, about 50 percent was removed from storage in the water-table part of the bolson aquifer, 25 percent was contributed by leakage from the alluvium, and the rest was derived from natural recharge. Since about 1917, however, the annual pumpage has exceeded natural recharge at an annually increasing rate, so that during 1968-73, natural recharge was equivalent to about 6 percent of the amount of water pumped.

\section{Simulations of Water-Level Changes}

When the model satisfactorily simulated the modeled parts of the hydrologic system, it was used to predict the effects of additional development from 1974 through 1990. The plan for development in the El Paso area assumed: (1) The total water requirements for all users in the E1 Paso area will increase about 29 percent; (2) 16 new wells producing 1,000 gal/min (3.79 $\mathrm{m}^{3} / \mathrm{min}$ ) each will be added and pumped about 50 percent of the time; and (3) the new wells will be drilled in existing or expanded well fields and will be located near existing pipelines.

In the Ciudad Juarez area, the plan assumed: (1) The water requirements will increase about 34 percent; (2) eight new wells producing 1,350 gal $/ \mathrm{min}\left(5: 11 \mathrm{~m}^{3} / \mathrm{min}\right)$ each will be added to the water-supply system and will be pumped about 50 percent of the time; and (3) the new wells will be located south and east of Ciudad Juarez.

The predicted water-leve1 declines for 1903-91 are shown on figure 13: The map shows a deep north-trending trough more or less centered along the axis of the fresh-water trough (fig. 7). The model indicates that water levels in the vicinity of the old mesa well field will decline an additional 47 feet $(14.3 \mathrm{~m})$ or a total decline of as much as 117 feet $(35.7 \mathrm{~m})$ since 1903. In Ciudad Juarez, the water levels are predicted to decline an additional 70 feet $(21.3 \mathrm{~m})$, which indicates a total decline of 140 feet (42:7 m) since 1903 . 


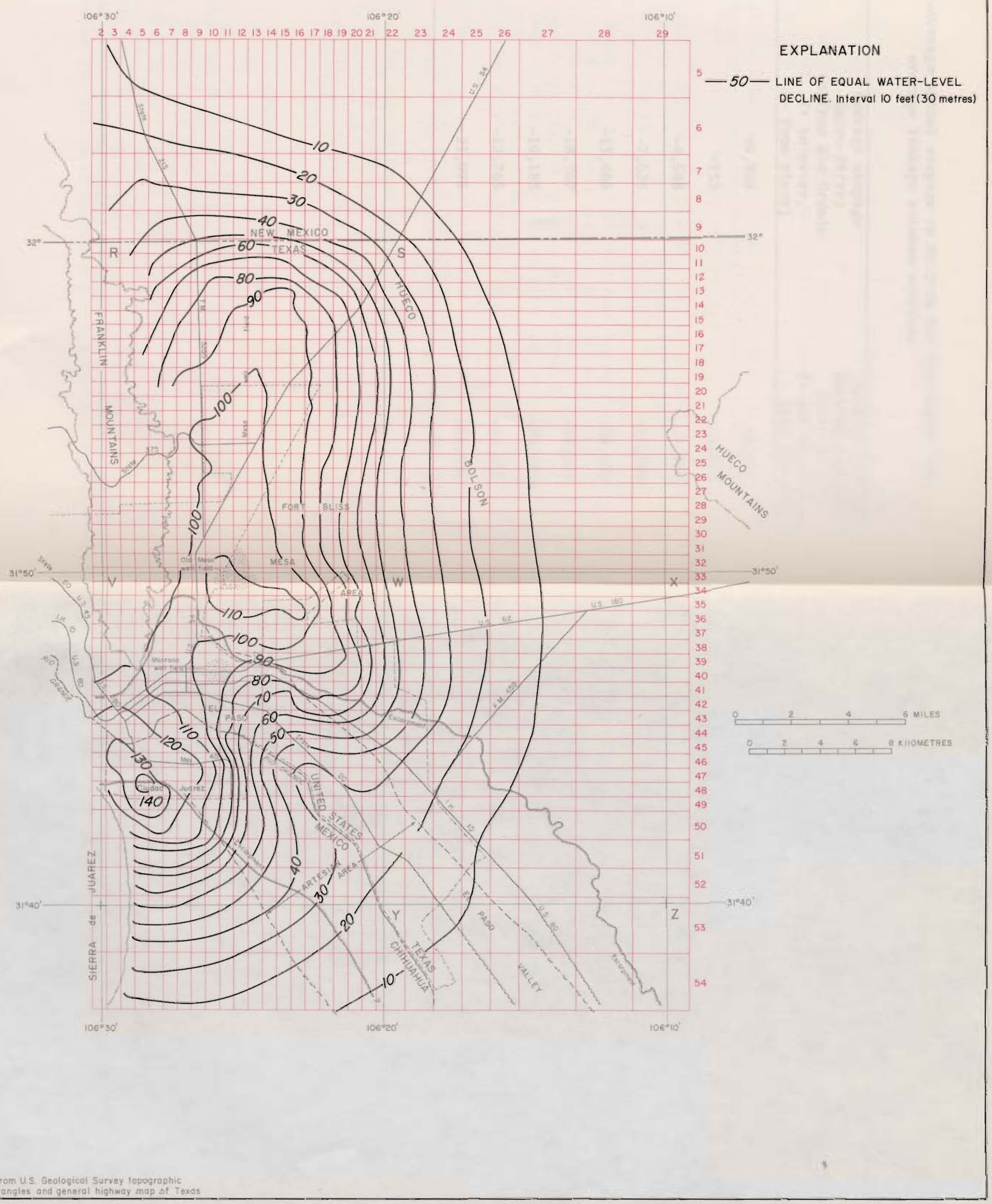

FIGURE 13. - Predicted decline in water levels for 1903-91 as computed by the digital model 
Table 1.--Average annual seepage to or from the Rio Grande and average leakage between aquifers

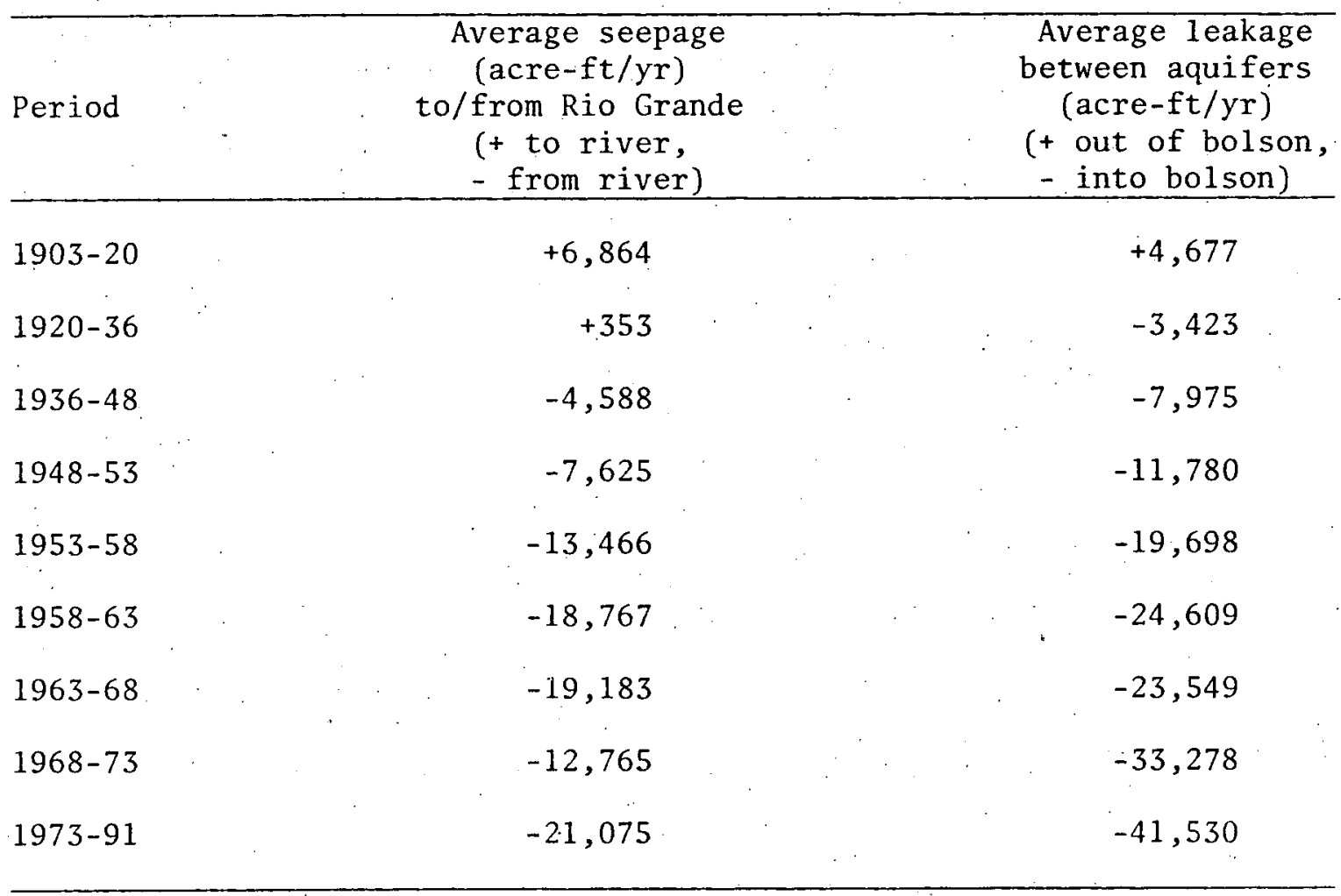


The model also shows that of the average annual withdrawal of 115,000 acre-feet (141.8 $\mathrm{hm}^{3}$ ) during 1973-91, nearly 60 percent would come from storage in the water-table part of the bolson aquifer and about. 28 percent would be derived from leakage from the alluvium. Seepage from the Rio Grande would account for slightly more than one-haif of the amount of water derived from leakage from the alluvium. At the end of 1991 , about 9.84 million acre-feet $\left(12,133 \mathrm{hm}^{3}\right)$ of fresh water would be in storage in the Texas part of the bolson, as compared to 10.6 million acre-feet $(13,070$ $\mathrm{hm}^{3}$ ) in storage in 1973 .

Table 2 shows the amount of fresh water in storage in the Texas part of the bolson, the amount removed from storage in Texas, and the amount removed from the entire bolson over the modeled period.

The reliability of these predictions of water-level changes depends not only on how closely future development conforms to the proposed plans of pumping; but also on the assumption that the flow in the Rio Grande will be sufficient to sustain the predicted amount of seepage from the river. The model shows that seepage from the river during 1973-91 will amount to 21,075 acre-feet $\left(26.0 \mathrm{hm}^{3}\right)$ per year or about 18 percent of the water pumped. This amount of seepage, which represents an increase of 65 percent over seepage in the previous pumping period (1968-73), results from expansion of the cone of depression in the artesian aquifer beyond the lined section of the river. If seepage from the river is reduced by either natural or artificial means, the predicted water-level declines may be conservative.

The model assumes that the transmissivity at a node will remain constant throughout the simulation period irrespective of the changes in saturated thickness. The model indicates that during 1973-91 this assumption probably was valid except at a few nodes. The coefficient of storage was modified in the artesian area in Texas where the piezometric surface was lowered below the top of the confining zone. The storage coefficient was not modified in the Mexican part of the artesian aquifer because the availability of data precluded an accurate definition of the base of the confining layer.

\section{SUMMARY AND CONCLUSIONS}

- During 1903-73, slightly more than 2 million acre-feet $\left(2,466 \mathrm{hm}^{3}\right)$ of water was pumped from the Hueco Bolson by all major users in the E1 Paso area. Except in the early years of development, the annual withdrawals of ground water far exceeded the natural recharge; consequently, the supply of fresh ground water in the bolson is being depleted. Effective management of the remaining suppiy depends upon the ability of water planners to predict the response of the aquifer to any particular plan of development. A twolayered digital model of the hydrology of the Hueco Bolson was developed to serve as an effective and economical tool to aid in making these predictions. 
Table 2.--Amount of fresh water in storage in the Texas part of the bolson and amount removed from storage

in Texas and from the entire bolson

(does not include alluvium)

\begin{tabular}{lcrc}
\hline Period & $\begin{array}{c}\text { Amount of fresh water } \\
\text { in storage, Texas } \\
\text { at end of period } \\
\text { (acre-ft) }\end{array}$ & $\begin{array}{c}\text { Amount removed from storage } \\
\text { during period }\end{array}$ \\
\hline $1903-20$ & $11,414,000$ & 33,700 & $\begin{array}{c}\text { Texas only } \\
\text { (acre-ft) }\end{array}$ \\
$1920-36$ & $11,372,000$ & 42,000 & 46,546 \\
$1936-48$ & $11,302,000$ & 70,000 & 58,028 \\
$1948-53$ & $11,247,000$ & 55,000 & 89,068 \\
$1953-58$ & $11,146,000$ & 101,000 & 65,684 \\
$1958-63$ & $11,007,000$ & 139,000 & 120,133 \\
$1963-68$ & $10,820,000$ & 187,000 & 167,987 \\
$1968-73$ & $10,643,000$ & 177,000 & 234,309 \\
$1973-90$ & $9,842,100$ & 800,900 & 256,500 \\
\hline
\end{tabular}


The model was calibrated for configuration of the predevelopment (1903) water surface, the configuration of the water surface in 1938, and for water-level declines during 1903-58 and 1903-73. The hydrologic budget for the model indicates that about 50 percent of the water pumped during 1903-73 was removed from storage in the bolson deposits (layer 2 of the model). About 25 percent of the water pumped was derived from leakage from the shailow alluvium in the Rio Grande Valley (model layer 1). Leakage from the alluvium is sustained by the release of water in storage in the alluvium and by seepage from the Rio Grande.

Calibration of the model indicated that: (1) The average specific yield is 0.1856 , rather than 0.15 as used in previous studies; (2) the natural recharge is only 5,640 acre-feet $\left(7.0 \mathrm{hm}^{3}\right)$ per year, or about 40 percent of the amount previously estimated; and (3) more data are needed in the Ciudad Juarez area.

The model shows that at the end of 1973, about 10,643,000 acre-feet $\left(13,123 \mathrm{hm}^{3}\right)$ of fresh water was in storage in the Texas part of the Hueco Bolson; previous studies (Knowles and Kennedy, 1958) estimated 6.2 million acre-feet $\left(7,645 \mathrm{hm}^{3}\right)$ in storage in New Mexico. On the basis of very limited information, 4 million acre-feet $\left(4,932 \mathrm{hm}^{3}\right)$ is estimated to be in storage in Mexico.

Analyses of a proposed plan for ground-water development from 1973 to 1991, in which pumping would be increased by 29 and 34 percent in E1 Paso and Ciudad Juarez, respectively, show that water levels would decline an additional 47 feet $(14.3 \mathrm{~m})$ in the Texas part of the bolson and 70 feet $(21.3 \mathrm{~m})$ in Ciudad Juarez, for a total decline since 1903 of 117 feet $(37.5 \mathrm{~m})$ and 140 feet $(42.7 \mathrm{~m})$ in the same areas. The model also indicated that as much as 9.8 million acre-feet $\left(12,083 \mathrm{hm}^{3}\right)$ of fresh water would still be in storage in the Texas part of the bolson in 1991.

The accuracy of the model to predict changes in water levels, leakage of water from the alluvium, and seepage from the Rio Grande is not uniform and is a function of the accuracy of the basic data and the assumptions made in model analyses. Where the data base is well defined, as in the Texas part of the bolson, the model predictions have an acceptable degree of accuracy; elsewhere, the accuracy of the model predictions decreases in nearly direct proportion to the reliability of the data base.

Although the model was used to predict the effect on water levels for only. one plan of development, it could also be used to predict the effects of changes in the amount of seepage from the Rio Grande. The model could be used in conjunction with a solute-transport model or other methods of problem solution to predict changes in the chemical quality of ground water in time and space due to a particular ground-water development plan. However, before the model can be used to solve chemical-quality changes, the problem will require better definition. 
The effectiveness of the digital model as a predictive tool for planning purposes can be increased considerably by additional revision and refinement. The present program of data exchange between the water agencies of Mexico and the United States, which began in 1974, may furnish some of the data needed to better define the hydrologic parameters in the Mexican part of the bolson. The data needed include: (1) The lateral extent of the artesian zone; (2) base and top of the fresh water; (3) specific yields; (4) distribution of pumpage; and (5) historical water levels. In other parts of the bolson, particularly in the undeveloped parts of the bolson in Texas and New Mexico, additional test drilling or development will be required to adequately expand the data base. Further refinement and revision of the model are indicated for the artesian part of the bolson in Texas. Of immediate concern is the wide range in the vertical permeabilities. 


\section{REFERENCES CITED}

Audsley, G. L., 1959, Records of wells and results of exploratory drilling in the El Paso Valley and Hueco Bolson southeast of El Paso, Texas: U.S. Geol. Survey open-file rept., $144 \mathrm{p}$.

Bredehoeft, J. D., and Pinder, G. F., 1970, Digital analyses of area flow in multiaquifer ground-water systems; a quasi three-dimensional model: Water Resources Res., vol. 6, no. 3, p. 883-888.

Davis, M. E., 1965, Development of ground water in the El Paso district, Texas, 1960-63, progress report no. 9: Texas Water Comm. Bu11. 65i4, 34 p., 9 figs., 6 pls.

Hantush, M. S., 1960, Modification of the theory of leaky aquifers: J. Geophys. Res., vol. 65, p. 3713-3725.

Knowles, D. B., and Kennedy, R. A., 1958, Ground-water resources of the. Hueco Bolson, northeast of E1 Paso, Texas: U.S. Geol. Survey WaterSupply Paper 1426, 186 p.

Leggat, E. R., 1962, Development of ground water in the El Paso district, Texas, 1955-60, progress report no. 8: Texas Water Comm. Bul1. 6204, $65 \mathrm{p}$.

Leggat, E. R., and Davis, M. E., 1966, Analog model study of the Hueco Bolson near El Paso, Texas: Texas Water Devel. Board. Rept. 28, 26 p., 13 figs.

Mattick, R. E., 1967, A seismic and gravity profile across the Hueco Bolson, Texas: U.S. Geol. Survey Prof. Paper 575-D, p. D85-D91:

Meyer, W. R., and Gordon, J. D., 1972, Development of ground water in the El Paso district, Texas, 1963-70: Texas Water Deve1. Board Rept. 153, 50 p., 17 figs.

Sayre, A. N., and Livingston, Penn, 1945, Ground-water resources of the E1 Paso area, Texas: U.S. Geo1. Survey Water-Supply Paper 919, 190 p.

Scalapino, R. A., 1949, Ground-water resources of the El Paso area, Texas, progress report no. 6: Texas Board Water Engineers dup1. rept., 25 p.

Smith, R. E., 1956, Ground-water resources of the E1 Paso district, Texas, progress report no. 7: Texas Board Water Engineers Bul1. 5603, 36 p. 